\title{
Sensorial and Microbial Study of Mushroom Pickle
}

\author{
Y. Prabhabati Devi ${ }^{*}$ and Kumari Sunita ${ }^{2}$ \\ ${ }^{1}$ Krishi Vigyan Kendra, Chandel ICAR-Manipur Centre, India \\ ${ }^{2}$ Krishi Vigyan Kendra Madhopur West Champaran, India \\ *Corresponding author
}

\section{A B S T R A C T}

\begin{tabular}{|l|}
\hline Ke y w or d s \\
Mushroom, \\
$\begin{array}{l}\text { Preservatives, } \\
\text { Sensory, Shelf life }\end{array}$ \\
\hline Article Info \\
\hline $\begin{array}{l}\text { Accepted: } \\
\text { 15 July 2020 } \\
\text { Available Online: } \\
\text { 10 August } 2020\end{array}$ \\
\hline
\end{tabular}

\section{Introduction}

Mushroom is a fleshy spore bearing fruiting body of fungus and very nutritious natural vegetable which contains high quality protein, vitamins and fibre. It is widely used as vegetables and also as a traditional medicine. Mushroom is highly perishable and starts deteriorating after a few hours depending upon the storage conditions. The shelf life of mushroom varies from 1-2 days at the ambient temperature due to its high moisture content, delicate texture and unique physiology (Sexena and Rai, 1990). The shelf life of mushroom can be extended by converting in to value added products. The value added products not only reduces the post harvest losses but also enhances the additional income to the mushroom growers and also provide neutraceutical low fat, protein rich food to the consumers (Arumuganathan et al., 2005). For increasing shelf life and also to increase the acceptability of the customer, mushroom is processed in the form of pickle. Pickle is a good appetizer consumed by all age of people which contain large amount of lactobacilli bacteria which are important for the digestion of grains and vegetables which have usual beneficial probiotic properties used by the body (Girdhari Lal et al., 2010). For pickling proper concentration of salt is very important for better shelf life and also to reduce the infestation of mold, yeast and bacteria. If salt 
concentration is less, the product gets slimy, soft and holds lots of water. Therefore the average salt concentration should not be less than 5.3 per cent (Rajablou et al., 2012). Sensory attribute is one of the important factors govern the consumers acceptance of food products and their purchase intent. The overall quality of any food product is related to several sensory attribute like appearance, texture and flavor. Texture is also one of the most important sensorial quantitative characteristics of pickle and its effect on product acceptance by the buyer is crucial (Sadeghizadeh et al., 2018) The process of pickle production is carried out under optimal condition, some changes occur in the texture of primary products which affects the quality of pickle as reported by Rodrige and Alvarruiz (2010). The problem of shelf life of mushroom pickle is higher in Manipur as it is highly perishable and hence an attempt is made to minimize the spoilage by the proper use of preservatives and also to select good quality fresh mushroom. The present study was undertaken to prepare mushroom pickle by use of different preservatives, to observe shelf life at different storage period, to evaluate the fungal growth and also to assess the overall acceptability of pickle by sensory evaluation.

\section{Materials and Methods}

The fresh, healthy oyster mushrooms were collected from Imphal market and other ingredients like spices, oil, acetic acid and vinegar were also collected from the local market. The experiment was conducted for a period of one year. Observation was recorded at the end of every month for the period of 2 month and at 2 month interval for the period up to12 month in order to see any change in colour, aroma, texture and appearance of fungus. Method of collection of sample along with treatment was shown in Table 1.

\section{Method of preparation oyster mushroom pickle}

The recipe of the oyster mushroom pickle is given in Table 2. Select fresh, mature mushroom and wash thoroughly with tap water to remove dust and dirt. Then remove stalk and cut in to desire shape and size. Blanch it for $3 \mathrm{~min}$ at a temperature $96-98^{\circ} \mathrm{C}$ and drain water properly. Fry spices in oil and add blanched mushroom and mix it properly. For storing pickle glass jar was sterialised at $100^{\circ} \mathrm{C}$ and dry it properly. In some treatment like $\mathrm{T}_{4}$ acetic acid was used and in $\mathrm{T}_{5}$ vinegar was used. For making mushroom pickle, mustard oil was heated and put all the spices, fry for few seconds and added the blanched mushroom and fry for 4-5 minutes in low flame till it blended properly. Salt and remaining oil were added. The fried mushroom pickle was cooled, filled in to sterilized glass bottle and sealed airtight. The flow chart for the preparation of mushroom pickle was shown in figure 1. For treatment like $\mathrm{T}_{4}$ acetic acid was added just before removing from fire and in case of $T_{5}$, blanched mushroom was cured in vinegar for $4 \mathrm{hrs}$ and drain vinegar water and other process remain same with other treatments.

\section{Results and Discussion}

\section{Sensory evaluation of oyster mushroom pickle}

The consumer's acceptability of processed mushroom pickle was evaluated by a taste testing panel. The hedonic rating test was used to determine the acceptability of pickle. The 30 panelists were selected from women entrepreneur of Imphal, Manipur. Panelists were asked to give scores for characteristic color, aroma, texture, taste and overall acceptability of the processed mushroom pickle. The scale was arranged such that $9=$ like extremely, $8=$ like very much, $7=$ like 
moderately, $6=$ like slightly, $5=$ neither like or dislike, $4=$ Dislike slightly, $3=$ Dislike moderately, 2 = Dislike very much, $1=$ Dislike extremely.

The mean score of performance mushroom pickles were presented in Table 5. From the table, it is seen that $T_{5}$ secured the highest score: 8.0 for colour, 7.8 for aroma, 7.8 for texture, for taste 8.2 and 8.0 for overall acceptability and was ranked 8 (like very much).

It also showed that $T_{1}$ got the lowest value than the other sample.T5 got the highest value which indicated that color, aroma texture, taste of $T_{5}$ is more acceptable than the others.

\section{Observation of fungus growth}

The fungal growth developed in mushroom pickle at different storage period was examined through visual observation. Details of the observation were given in Table 3. Up to 30 days storage, no fungal growth was observed. During 2nd month of storage, the fungal growth was observed in $\mathrm{T}_{1}$ due to low concentration of salt and mustard oil. Whitish fungal growth was observed on the surface of the pickle, it may be due to spices, other ingredients, from the air or from lid of the jar. From $6^{\text {th }}$ months to 12 months, excessive growth of fungus was observed in case of $T_{1}$ and $T_{2}$ and other treatments like $T_{3}$ there was slight growth by fungus from $8^{\text {th }}$ months onwards.

Table.1 Method of selection of sample with different treatment

\begin{tabular}{|c|c|}
\hline Sample & Treatment \\
\hline Sample 1 & $\begin{array}{l}\text { Blanched oyster mushroom }+3.5 \text { per cent } \text { salt }+ \text { spice }+15 \text { per cent mustard oil and store in } \\
\text { sterialised glass bottle }\end{array}$ \\
\hline Sample 2 & $\begin{array}{l}\text { Blanched oyster mushroom }+5 \text { per cent salt }+ \text { spice }+20 \text { per cent mustard oil and store in } \\
\text { sterialised glass bottle }\end{array}$ \\
\hline Sample 3 & $\begin{array}{l}\text { Blanched oyster mushroom }+6 \text { per cent salt }+ \text { spice }+25 \text { per cent mustard oil and store in } \\
\text { sterialised glass bottle }\end{array}$ \\
\hline Sample 4 & $\begin{array}{l}\text { Blanched oyster mushroom }+8 \text { per cent salt }+ \text { spice }+30 \text { per cent mustard oil }+1.5 \text { per } \\
\text { cent Acetic acid and store in sterialised glass bottle }\end{array}$ \\
\hline Sample 5 & $\begin{array}{l}\text { Vinegar cured blanched oyster mushroom }+10 \text { per cent salt }+ \text { spice }+35 \text { per cent mustard } \\
\text { oil and store in sterialised glass bottle }\end{array}$ \\
\hline
\end{tabular}

Table.2 Recipe of oyster mushroom pickle

\begin{tabular}{|l|c|c|c|c|c|}
\hline \multirow{2}{*}{ Ingredients } & \multicolumn{5}{|c|}{ Treatments } \\
\cline { 2 - 6 } & T1 & T2 & T3 & T4 & T5 \\
\hline Blanched oyster mushroom (kg) & 1 & 1 & 1 & 1 & 1 \\
\hline Mustard Oil (ml) & 100 & 150 & 200 & 250 & 300 \\
\hline Salt (g) & 30 & 50 & 60 & 80 & 100 \\
\hline Chilli Powder (g) & 10 & 20 & 30 & 35 & 40 \\
\hline Jira Powder(g) & 10 & 10 & 10 & 10 & 10 \\
\hline White Mustard Seed Powder(g) & 10 & 15 & 20 & 20 & 20 \\
\hline Coriander Powder (g) & 5 & 10 & 10 & 10 & 10 \\
\hline Turmeric Powder (g) & 10 & 15 & 20 & 20 & 20 \\
\hline Vinegar & - & - & - & - & 1 lt \\
\hline Acetic Acid & - & - & - & $25 \mathrm{ml}$ & - \\
\hline
\end{tabular}


Table 3 Visual observation of fungus growth developed in oyster mushroom pickle at different storage period

\begin{tabular}{|c|c|c|c|c|c|}
\hline $\begin{array}{l}\text { Storage } \\
\text { Period } \\
\text { (Month) }\end{array}$ & Sample & Fungal Growth & $\begin{array}{l}\text { Storage Period } \\
\text { (Month) }\end{array}$ & Sample & Fungal Growth \\
\hline 1month & $\begin{array}{l}\text { S1 } \\
\text { S2 } \\
\text { S3 } \\
\text { S4 } \\
\text { S5 }\end{array}$ & $\begin{array}{l}\text { No Growth } \\
\text { No Growth } \\
\text { No Growth } \\
\text { No Growth } \\
\text { No Growth }\end{array}$ & 8 month & $\begin{array}{l}\text { S1 } \\
\text { S2 } \\
\text { S3 } \\
\text { S4 } \\
\text { S5 }\end{array}$ & $\begin{array}{l}\text { Excessive } \\
\text { Growth } \\
\text { Excessive } \\
\text { Growth } \\
\text { Slightly Growth }\end{array}$ \\
\hline 2 month & $\begin{array}{l}\text { S1 } \\
\text { S2 } \\
\text { S3 } \\
\text { S4 } \\
\text { S5 }\end{array}$ & $\begin{array}{l}\text { Slightly Growth } \\
\text { No Growth } \\
\text { No Growth } \\
\text { No Growth } \\
\text { No Growth }\end{array}$ & 10 month & $\begin{array}{l}\text { S1 } \\
\text { S2 } \\
\text { S3 } \\
\text { S4 } \\
\text { S5 }\end{array}$ & $\begin{array}{l}\text { Excessive } \\
\text { Growth } \\
\text { Excessive } \\
\text { Growth } \\
\text { Slightly growth }\end{array}$ \\
\hline 4 month & $\begin{array}{l}\text { S1 } \\
\text { S2 } \\
\text { S3 } \\
\text { S4 } \\
\text { S5 }\end{array}$ & $\begin{array}{l}\text { Slightly Growth } \\
\text { Slightly Growth } \\
\text { No Growth } \\
\text { No Growth } \\
\text { No Growth }\end{array}$ & 12 month & $\begin{array}{l}\text { S1 } \\
\text { S2 } \\
\text { S3 } \\
\text { S4 } \\
\text { S5 }\end{array}$ & $\begin{array}{l}\text { Excessive } \\
\text { Growth } \\
\text { Excessive } \\
\text { Growth } \\
\text { Excessive }\end{array}$ \\
\hline 6 month & $\begin{array}{l}\text { S1 } \\
\text { S2 } \\
\text { S3 } \\
\text { S4 } \\
\text { S5 }\end{array}$ & $\begin{array}{c}\text { Excessive Growth } \\
\text { Slightly Growth } \\
\text { No Growth } \\
\text { No Growth } \\
\text { No Growth }\end{array}$ & & & \\
\hline
\end{tabular}

Table.4 Storage life of oyster mushroom pickle

\begin{tabular}{|c|l|l|l|l|l|}
\hline $\begin{array}{c}\text { Shelf life } \\
\text { (months) }\end{array}$ & Sample & \multicolumn{1}{|c|}{ Colour } & \multicolumn{1}{|c|}{ Flavour } & \multicolumn{1}{|c|}{ Texture } & \multicolumn{1}{c|}{ Remark } \\
\hline $\mathbf{1}$ & S1 & No change & No off flavour & Firm & Good \\
& S2 & No change & No off flavour & Firm & Good \\
& S3 & No change & No off flavour & Firm & Good \\
& S4 & No change & No off flavour & Firm & Good \\
& S5 & No change & No off flavour & Firm & Good \\
\hline $\mathbf{2}$ & S1 & Slightly change & Slightly off flavour & Slightly soft & Fair \\
& S2 & No change & No off flavour & Firm & Good \\
& S3 & No change & No off flavour & Firm & Good \\
& S4 & No change & No off flavour & Firm & Good \\
& S5 & No change & No off flavour & Firm & Good \\
\hline \multirow{4}{*}{ S1 } & Change & Off flavour & Soft & Slightly spoiled \\
& S2 & Slightly change & Slightly off flavour & Slightly soft & Fair \\
& S3 & No change & No off flavour & Firm & Good \\
& S4 & No change & No off flavour & Firm & Good \\
& S5 & & No off flavour & Firm & Good \\
\hline \multirow{6}{*}{6} & S1 & Change & Off flavour & Extremely soft & Spoiled \\
& S2 & Change & Off flavour & Soft & Slightly spoiled \\
\hline
\end{tabular}




\begin{tabular}{|c|l|l|l|l|l|}
\hline & S3 & Slightly change & Slightly off flavour & Slightly Soft & Fair \\
& S4 & No change & No off flavour & Firm & Good \\
& S5 & No change & No off flavour & Firm & Good \\
\hline $\mathbf{8}$ & S1 & Change & Off flavour & Extremely soft & Completely spoiled \\
& S2 & Change & Off flavour & Extremely soft & Spoiled \\
& S3 & Change & Off flavour & Soft & Slightly spoiled \\
& S4 & No change & No off flavour & Firm & Good \\
\hline \multirow{4}{*10}{} & S5 & No change & No off flavour & Firm & Good \\
\hline & S1 & Change & Off flavour & Extremely soft & Completely spoiled \\
& S2 & Change & Off flavour & Extremely soft & Spoiled \\
& S3 & Change & Off flavour & Extremely soft & Spoiled \\
& S4 & Slightly change & Slightly off flavour & Soft & Slightly spoiled \\
& S5 & No change & No off flavour & Firm & Good \\
\hline & S1 & Change & Off flavour & Extremely soft & Completely spoiled \\
& S2 & Change & Off flavour & Extremely soft & Completely spoiled \\
& S3 & Change & Off flavour & Extremely soft & Spoiled \\
& S4 & Change & Off flavour & Soft & Slightly spoiled \\
& S5 & No change & No off flavour & Firm & Good \\
\hline
\end{tabular}

Fig.1 Flow chart for the preparation of mushroom pickle

\section{Treatment -1}

Select fresh and healthy oyster mushroom

Remove stalk and wash to remove dust

Cut in to pieces and blanched for 3 mins

Washed with cold water and strained water

Fry spices in oil

Add blanched mushroom to fried spices

Add salt and fry the mixture for about 10 minutes

Cool and fill in sterilized jar

Seal and store in cool dry place 
Table.5 Mean score for performance of colour aroma, texture, taste and overall acceptability of various sample of oyster mushroom pickle

\begin{tabular}{|c|c|c|c|c|c|}
\hline \multirow{2}{*}{$\begin{array}{c}\text { Sample } \\
\text { Code }\end{array}$} & \multicolumn{5}{|c|}{ Sensory attributes } \\
\hline S1 & Colour & Aroma & Texture & Taste & Overall acceptability \\
\hline S2 & 7.1 & 6.5 & 7.0 & 6.5 & 6.6 \\
\hline S3 & 7.3 & 6.5 & 7.3 & 6.8 & 6.8 \\
\hline S4 & 7.5 & 6.8 & 7.5 & 7.0 & 7.2 \\
\hline S5 & 7.7 & 7.2 & 7.5 & 7.5 & 7.5 \\
\hline
\end{tabular}

In case treatment like $\mathrm{T}_{4}$ fungal growth started from 10 months onwards and in case of $\mathrm{T}_{5}$, there was no fungal appearance on the surface of the pickle due to high concentration of salt, mustard, acetic acid and vinegar. The covering of oil as well as proper concentration of salt helped to prevent microbial contamination and vinegar and acetic acid helped to maintain the proper $p H$ of the pickle.

\section{Storage studies of oyster mushroom pickle}

Mushroom pickles were stored at room temperature. The deterioration of the product was observed at a regular interval of one month upto 2 months and 2 months interval for a period upto 12 months. The change in color, aroma and texture were observed for a period of 1 year. Five different samples of mushroom pickles were used for storage studies at room temperature of $26^{\circ}-30^{\circ} \mathrm{C}$ from 1 month to 12 months. The effect of storage time on physical properties such as colour, aroma and texture of the pickles were studied. The processed mushroom pickles were in good condition up to 30 days in case of $\mathrm{T}_{1}$ and in case of $\mathrm{T}_{5}$, it was up to 12 months. For $T_{1}$ and $T_{2}$ change in color, flavour and texture started from $2^{\text {th }}$ and $4^{\text {th }}$ months onwards which was shown in Table 4. This may be due to lack of proper concentration of preservatives like salt and mustard oil. In case of $\mathrm{T}_{3}$, changes started from 6 months onwards and for $\mathrm{T}_{4}$, changes of colour, texture and appearance started from 10 months onwards due to lack of right concentration of preservatives like vinegar and acetic acid. For $\mathrm{T}_{5}$, there was no change in color, flavour and texture up to 12 months as the blanched bitter mushroom was cured in vinegar for 4 hours and right concentration of salt and mustard oil were added which helped to extend the shelf life up to 12 months.

In conclusion the mushroom pickle is highly perishable. So, proper preservatives like salt, mustard oil, acetic acid and vinegar should be used in proper concentration to reduce the microbial growth and also to extend the shelf life of the pickle. From this study, it was found that fungal growth was a great problem of pickle. If we add proper concentration of preservatives, the fungal growth becomes very low. The panelists also tested the product and gave the score for color, aroma, texture, taste and overall acceptability. The score of panel test indicated that among the five treatments, the pickle which was prepared with vinegar cured blanched mushroom $\left(\mathrm{T}_{5}\right)$ was the most acceptable. In case of shelf life, $\mathrm{T}_{5}$ have better shelf life than other 4 treatment. It was proved that $T_{5}$ is the best method for extending the shelf life and also for improving the quality of the mushroom pickle. This study gives a good prospect on processing of mushroom. This technology may be adopted on large scale by the rural youth, women entrepreneurs and farm women in order to generate income and also for increasing employment opportunity for sustaining livelihood. 


\section{References}

Arumuganathan, T, R.D. Rai and A.K. Hemakar (2005) 'Studies on development of value added products from fresh button mushroom Agaricus bisporus'. Mushroom Research 14(2)

Goel, A. K., Kumar, R. and Mann, S. S. (2007). Postharvest Management and Value Addition. Daya Publishing House, Trinagar, New Delhi - 110035.

Girdhari, L. and Siddapa, G. S. (2010) Chutney, sauce, pickle, preservation of fruits and vegetables. ICAR Publications, New Delhi.

Rajablou et at. (2012) Make pickles probiotic with using strain Lactobacillus plantanum native. Journal of Food Technology and Nutrition. 9(2).

Rodrigo, M and Alvarruiz, A (2010) The influence of fermentation and pasteurization on the texture of cucumber pickle. Journal of Food Engineering, 7(2)
Sadeghizadeh, Yazdi. J., Behradkia, V., Hozoori, M. (2018) 'Evaluation of sensorial, chemical and microbial characteristic of pickled cucumber supplied in Shiraz'. Journal of Nutrition and Food Security, 3 (2).

Sangeeta. A., Pingale and Vaibhav, R., Dabhade. (2015) 'Development and sensory attributes of the pickle made from Bitter gourd and Bottle gourd'. Int J Sci Res, Vol (4) Issue 10.

Saxena, S and R.D. Rai (1990). 'Post Harvest Technology of Mushroom'. Technical Bulletin No.2. NRCM, Solan, India

Shahzor, G. K. and Wen, Z. (2015) 'Effects of processing techniques on the quality and acceptability of Auricularia auricular Mushroom pickle'. Journal of Food and Nutrition Research 3(1)

Srivastava, R. P. and Kumar, S. (2003) Fruit and Vegetable Preservation. Indian Food Packer, Lucknow.

\section{How to cite this article:}

Prabhabati Devi, Y. and Kumari Sunita. 2020. Sensorial and Microbial Study of Mushroom Pickle. Int.J.Curr.Microbiol.App.Sci. 9(08): 1458-1464. doi: https://doi.org/10.20546/ijcmas.2020.908.167 